\title{
NORMA TES DAYA LEDAK, KECEPATAN, DAYA TAHAN SEPAKBOLA UNTUK KATEGORI USIA 13 - 14 TAHUN
}

\author{
Iwan Hermawan, Lambertus Leo Sergio Batista Sili \\ Fakultas Ilmu Keolahragaan, Universitas Negeri Jakarta, Jakarta, Indonesia \\ Correspondence: Fakultas Ilmu Keolahragaan, Universitas Negeri Jakarta, Jakarta, \\ Indonesia. E-mail:
}

\begin{abstract}
Abstrak
Penelitian ini adalah untuk mencari norma tes, daya ledak, kecepatan, daya tahan dalam sepak bola untuk kategori 13-14 tahun. Metode penelitian yang digunakan dalam penelitian ini adalah metode penelitian deskriptif. Penelitian deskriptif adalah suatu metode dalam meneliti status sekelompok manusia, suatu objek, suatu set kondisi, suatu sistem pemikiran, ataupun suatu kelas peristiwa pada masa sekarang. Berikut hasil dari penelitian yang telah dilakukan.(1).Untuk data penjaga gawang:Telah didapat norma tes fisik Daya Ledak yaitu untuk kategori Baik Sekali lebih besar dari 74, Telah didapat norma tes fisik Kecepatan yaitu untuk kategori Baik Sekali lebih kecil dari 5,47, Telah didapat norma tes fisik Daya Tahan yaitu untuk kategori Baik Sekali lebih besar dari 42,3.(2). Untuk data pemain belakang. Telah didapat norma tes fisik Daya Ledak yaitu untuk kategori Baik Sekali lebih besar dari 71, Telah didapat norma tes fisik Kecepatan yaitu untuk kategori Baik Sekali lebih kecil dari 5,67, Telah didapat norma tes fisik Daya Tahan yaitu untuk kategori Baik Sekali lebih besar dari 44,7.(3) Untuk data pemain tengah. Telah didapat norma tes fisik Daya Ledak yaitu untuk kategori Baik Sekali lebih besar dari 67. Telah didapat norma tes fisik Kecepatan yaitu untuk kategori Baik Sekali lebih kecil dari 5,64. Telah didapat norma tes fisik Daya Tahan yaitu untuk kategori Baik Sekali lebih besar dari 45,8, (4) Untuk data pemain depan. Telah didapat norma tes fisik Daya Ledak yaitu untuk kategori Baik Sekali lebih besar dari 61.Telah didapat norma tes fisik Kecepatan yaitu untuk kategori Baik Sekali lebih kecil dari 5,31. Telah didapat norma tes fisik Daya Tahan yaitu untuk kategori Baik Sekali lebih besar dari 44,2
\end{abstract}

\section{Kata Kunci: Norma Tes Sepakbola Kategori 13-14 Tahun}

\section{Pendahuluan}

Menjadi atlet sepakbola berkualitas pada jaman modern sekarang ini tidaklah mudah, perlu adanya pembinaan dari usia dini yang dilaksanakan melalui proses pengembangan secara terstruktur, berjenjang, dan berkelanjutan dengan dukungan ilmu pengetahuan dan teknologi di bidang olahraga. Hal ini dapat dilihat dari banyaknya didirikannya SSB (Sekolah Sepak Bola) dengan tujuan memberikan berbagai pengetahuan serta melatih fisik dan keterampilan dalam bermain sepakbola secara bertahap dan berkesinambungan sesuai dengan karakteristik usia pemain.

Setiap pemain yang berlatih harus ada suatu wadah sebagai hasil dari latihan. Itu dapat dilihat dengan mengikuti kejuaraan atau kompetisi antar kelompok umur sesuai dengan karakteristik pemain, dengan diadakan kejuaraan atau kompetisi seperti ini diharapkan setiap pemain dapat mengembangkan keterampilan teknik disertai peningkatan kondisi fisik yang baik dan juga menjadi pengalaman pemain dalam bermain sepakbola. 
Perkembangan pemain muda dimulai dari youth phase atau usia 13 - 14 tahun, artinya di phase inilah pemain sudah dilatih teknik serta taktik bermain, tetapi juga yang harus diketahui oleh semua pelatih untuk usia dini melatih pembentukan kondisi fisik yang melibatkan komponen-komponen biomotorik yang menjadi landasan dasar seorang pemain muda untuk bermain sepakbola ke tingkat yang lebih tinggi itu yang sangat penting. Karena untuk dapat menampilkan permainan yang bagus dan menarik dalam permainan sepakbola tidak hanya ditunjang dari keterampilan-keterampilan dasarnya saja. Tetapi juga harus ditunjang dengan memiliki kondisi fisik yang bagus pula, agar setiap pemain dapat bermain selama 90 menit. Usia mudalah pembentukan kondisi fisik yang baik dan merupakan elemen penting di dalam menunjang performa setiap pemain.

\section{Daya Ledak (Power)}

Daya ledak atau yang biasa disebut dengan power merupakan salah satu komponen biomotorik yang diidentikkan dengan kekuatan eksplosif (eksplosif strength). Dalam kepentingan olahraga, daya ledak yang dimaksud adalah daya ledak eksplosif, yang terdiri atas dua kelompok biomotorik yaitu unsur kekuatan (strength) dan kecepatan (speed).

Komponen daya ledak merupakan komponen yang penting untuk pemain sepak bola. Selain itu daya ledak sangat menarik untuk dibahas karena didalamnya terdapat dua komponen yang menjadi landasan daya ledak seorang pemain, yaitu kekuatan yang besar dan kecepatan yang tinggi. Daya ledak terjadi pada saat pemain melakukan gerakan yang kuat dan cepat. Seperti pada saat melompat untuk menyundul bola, menembak bola ke arah gawang, mengubah arah (changing direction) dan yang lainnya. Daya ledak merupakan gabungan dari 2 komponen fisik yaitu kekuatan maksimal dan kecepatan tinggi. Kekuatan otot tungkai yang dipakai oleh seorang pemain sepakbola pada saat melompat dapat dilihat dari gambar di bawah ini :

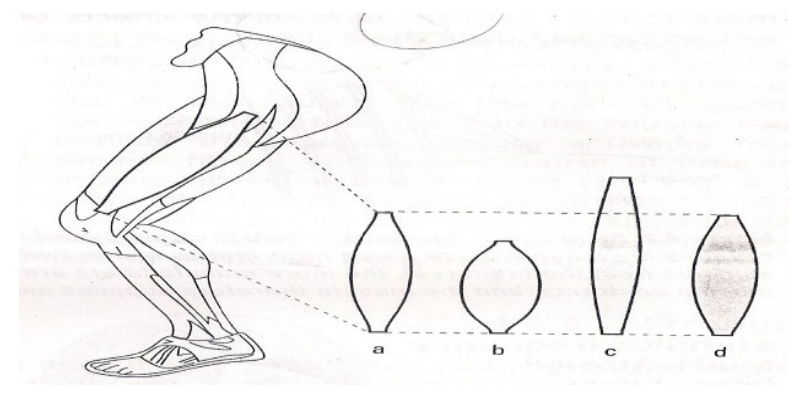

Gambar.1. Otot tungkai

Pelaksanaan tes daya ledak dengan menggunakan alat tes vertical jump modifikasi (Sports Skill Test)

a. Tujuan Tes,

Tes ini bertujuan untuk mengetahui kemampuan daya ledak pemain

b. Alat dan Perlengkapan Tes

Alat Modified of Vertical Jump

c. Gambar tes 


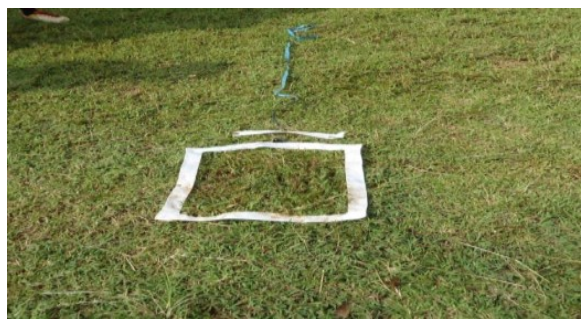

\section{d. Pelaksanaan Tes}

1. Testee berdiri tepat ditengah-tengan kotak alat tes modifikasi vertical jump dengan tegap dan rileks.

2. Setelah testee berdiri tepat di tengah-tengan kotak alat tes modifikasi vertical jump, maka tester akan mengikat pita ukuran ke testee

3. Setelah ada aba-aba "ya" testee harus meloncat setinggi-tingginya dengan maksimal namun pada saat mendarat kaki/ posisi testee harus kembali tepat berada ditengahtengah alat tes modifikasi tes vertical jump.

4. Kemudian setelah testee meloncat dengan setinggi-tingginya maka hasil yang diperoleh testee dicatat pada formulir tes dan testee diperintahkan duduk untuk menunggu tes selanjutnya

\section{e. Penilaian}

1. Penilaian yang dicatat adalah seberapa tinggi loncatan pemain/ testee pada saat melakukan kesempatan tes daya ledak

2. Hasil yang dicatat adalah dalam bentuk satuan centimeter

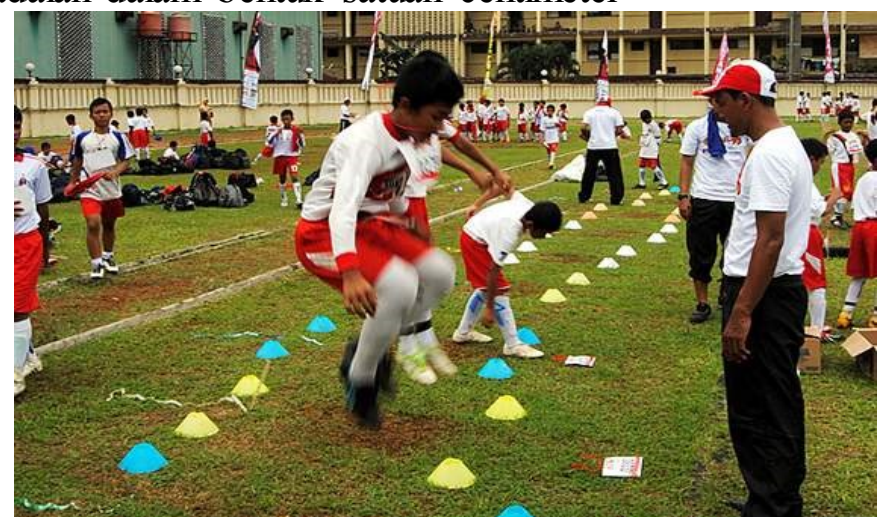

Gambar 3: Pelaksanaan Tes Vertical Jump Milan Junior Camp

\section{Kecepatan (Speed)}

Kecepatan atau yang biasa disebut dengan speed adalah digambarkan sebagai unsur Caristocratic permainan. Kecepatan adalah faktor yang memungkinkan individu untuk melaksanakan tindakan motor secepat mungkin, karena fungsi proses sistem neuromuscular dan proses kekuatan tubuh. Seluruh cabang olahraga menempatkan kecepatan sebagai komponen fisik yang paling penting, dikarenakan merupakan salah satu faktor penentu di beberapa cabang olahraga permainan khususnya cabang olahraga sepakbola. Menurut Sajoto yang 
dimaksud dengan kecepatan adalah: Kemampuan seseorang untuk mengerjakan gerakan berkesinambungan dalam bentuk yang sama dengan waktu yang sesingkat-singkatnya.

Pelaksanaan tes kecepatan dengan menggunakan tes sprint 40 meter.

- $\quad$ Standing Sprint

- Jarak melakukan Sprint, panjang 40 meter dan memiliki 5 lintasan sprint

- Terdapat 5 lintasan sprint dengan jarak setiap kotak 2 meter

- Peserta memiliki satu kali kesempatan untuk melakukan sprint

- Waktu tercepat yang akan di hitung

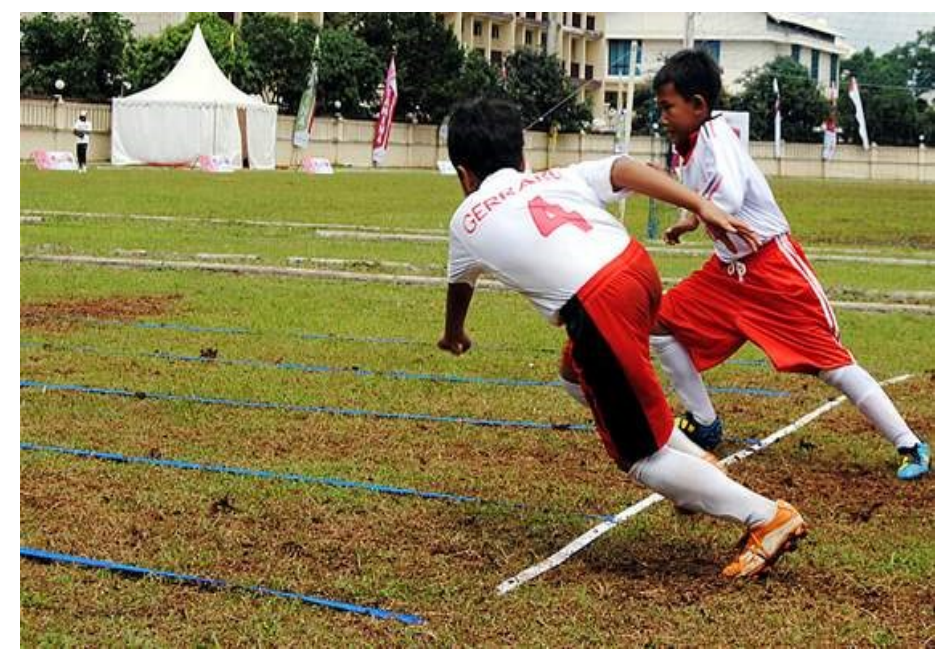

Gambar 4: Pelaksanaan tes sprint 40 meter

\section{Daya Tahan (Endurance)}

Dalam cabang olahraga sepakbola daya tahan merupakan bagian yang paling esensial dikarenakan merupakan bagian terpenting dan menjadi permasalahan paling kompleks yang perlu penanganan secara serius dan sabar dengan melihat kenyataan yang terjadi dilapangan. Seorang pemain sepakbola dalam upaya peningkatan daya tahan khususnya di Indonesia masih jauh dari harapan dengan standar kriteria yang telah ditetapkan untuk menjadi seorang pemain profesional.

Dijelaskan juga di dalam " The Player of Tomorrow" dari FIFA bahwa pengembangan kapasitas daya tahan usia 13 - 14 tahun adalah sebagai berikut:

1. Daya tahan dasar (kapasitas aerobik) telah cukup mempengaruhi di semua kualitas daya tahan. Selain itu, efek bermanfaat pada kesehatan secara keseluruhan tak terbantahkan, dan perannya dalam pencegahan kecelakaan dan cedera tidak dapat diabaikan. Ini juga membantu pemulihan untuk sebagian besar dan berperan dalam pelaksanaan keterampilan teknis. Akibatnya, awal pelatihan ketahanan akan diarahkan meningkatkan ketahanan dasar ini dan kapasitas aerobik (70 - 80\% of MHR / maximum heart rate).

2. Anak-anak yang bermain sepak bola dan olahraga lainnya secara teratur akan mengembangkan ketahanan dasar dengan mudah. Terus-menerus

latihan dengan bola, berlatih bergerak dengan latihan interval atau praktek bermain adalah cara-cara efektif mengembangkan ketahanan dasar ini. 
3. Bekerja pada intensitas sedang (70 - $80 \%$ of MHR) membantu untuk membangun oksigen cadangan tubuh, serta sistem seluruh organik dan jantung. Dari usia 12 - 13 dan seterusnya, setiap hari sesi latihan pertandingan dan latihan terpadu (misalnya berlari dengan bola, melewati latihan dan simulasi pertandingan situasi) harus dimasukkan dalam latihan.

4. Kekuatan aerobik (AP) dapat dikembangkan secara bertahap dari usia 14 - 15 dan seterusnya dengan interval atau latihan intermiten. Ini akan memiliki efek pada keluaran jantung, dan akan membantu tubuh menjadi terbiasa untuk bekerja dalam keadaan kelelahan (at $80-90 \%$ of MHR). Praktek pertandingan ukuran lapangan

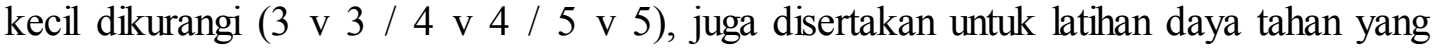
spesifik (aerobic/anaerobic).

5. Daya tahan berkualitas tinggi yang bekerja di usia pubertas akan menentukan penampilan para pemain dengan kapasitas yang dimilikinya untuk di kemudian usia dewasa, sejak individu memiliki sebuah kapasitas yang lebih besar untuk sebuah toleransi yang lebih besar untuk tenaga pada usianya.

Pelaksanaan tes daya tahan menggunakan bleep test :

\section{- Persiapan Pelaksanaan Tes}

- Ukuran panjang lintasan lari adalah 20 meter dan beri tanda di kedua ujungnya.

- Pastikan kaset atau CD yang berisi panduan tes MFT telah diseting dengan benar.

- Sebelum melakukan tes jangan makan selama dua jam sebelum mengikuti tes, pakai pakaian olahraga dan sepatu olahraga yang tidak licin.

- Melakukan peregangan terutama untuk otot-otot tungkai sebelum melaksanakan tes. Disarankan juga untuk melakukan pemanasan secara umum sehingga secara fisik dan mental siap melakukan tes.

- Setelah melakukan tes lakukan pendinginan dengan melakukan peregangan.

\section{- Pelaksanaan Tes}

- Hidupkan tape recorder yang berisi kaset atau CD panduan tes MFT mulai dari awal lalu ikuti petunjuknya.

- Pada bagian permulaan, jarak dua sinyal tut menandai suatu interval satu menit yang terukur secara akurat.

- Selanjutnya terdengan penjelasan ringkas mengenai pelaksanaan tes yang mengantarkan pada perhitungan mundur selama lima detik menjelang dimulainya tes.

- Setelah itu akan keluar sinyal tut pada beberapa interval yang teratur.

- Peserta tes diharapkan berusaha agar dapat sampai ke ujung yang berlawanan bertepatan dengan sinyal tut yang pertama berbunyi, untuk kemudian berbalik dan berlari ke arah yang berlawanan.

- Setiap kali sinyal tut berbunyi peserta tes harus sudah sampai di salah satu ujung lintasan lari yang di tempuhnya.

- Selanjutnya interval satu menit akan berkurang sehingga untuk menyelesaikan level selanjutnya peserta tes harus berlari lebih cepat.

- Setiap kali peserta tes menyelesaikan jarak 20 meter, posisi salah satu kaki harus tepat menginjak atau melewati batas 20 meter, selanjutnya berbalik dan menunggu sinyal berikutnya untuk melanjutkan lari ke arah berlawanan.

- Setiap peserta tes harus berusaha bertahan selama mungkin, sesuai dengan kecepatan yang telah diatur. Jika peserta tes tidak mampu berlari mengikuti kecepatan tersebut maka peserta harus berhenti atau dihentikan dengan ketentuan : 
- Jika peserta tes gagal mencapai dua langkah atau lebih dari garis batas 20 meter setelah sinyal tut berbunyi, pengetes memberi toleransi 1 x 20 meter, untuk memberi kesempatan peserta tes menyesuaikan kecepatannya.

- Jika pada masa toleransi itu peserta tes gagal menyesuaikan kecepatannya, maka dia dihentikan dari kegiatan tes.

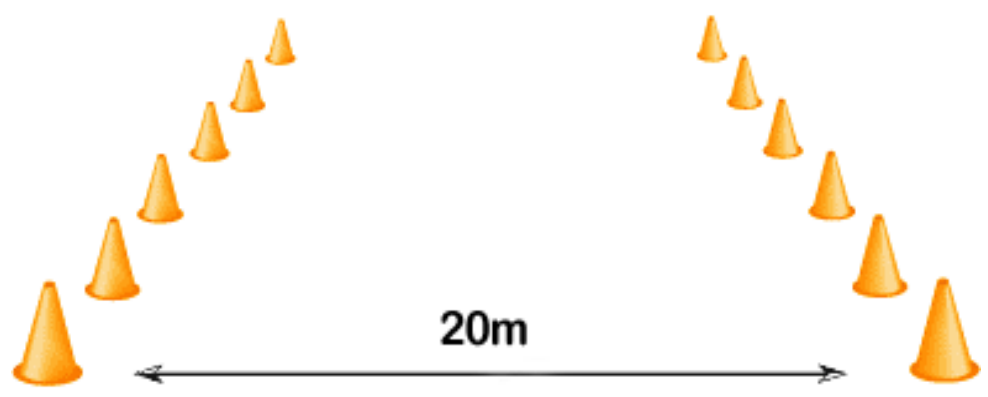

Gambar 5: Pelaksanaan Tes bleep

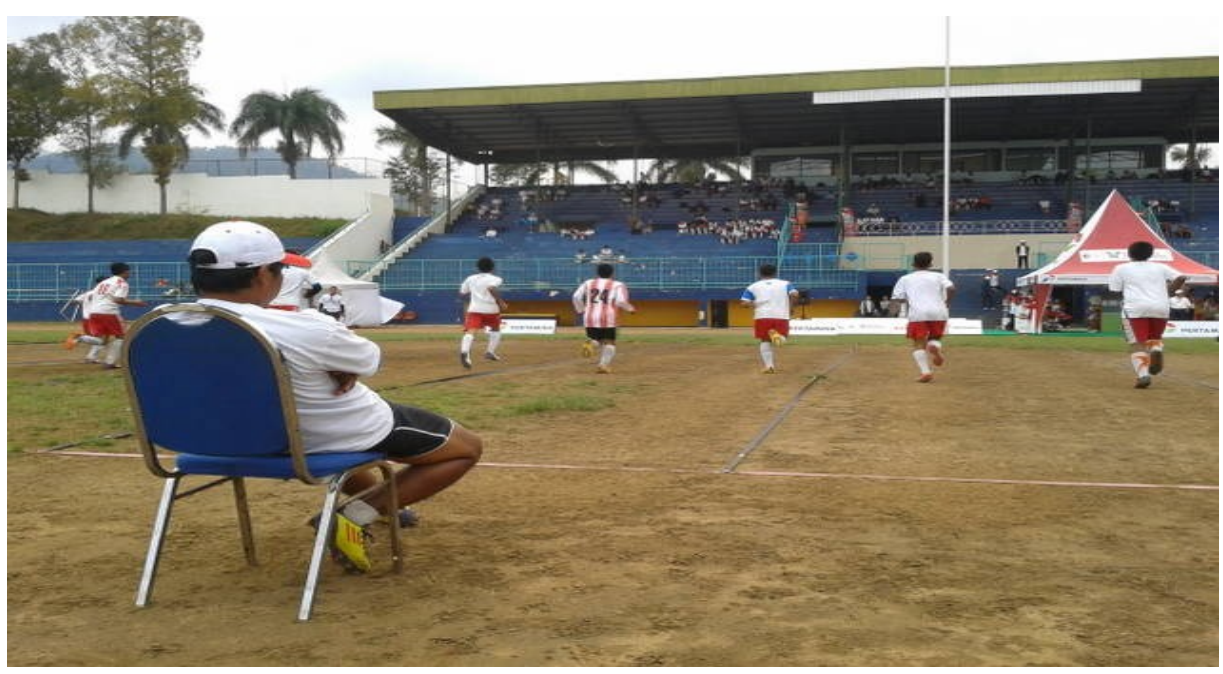

Gambar 6: Pelaksanaan Tes bleep Milan Junior Camp Sumber : Milan Junior Camp

\section{Hakikat Sepakbola}

Sepakbola adalah permainan bola beregu yang dimainkan oleh sebelas orang pemain, dimana pemain yang bermain mempunyai peran dan posisinya masing-masing yaitu penjaga gawang, pemain bertahan, pemain tengah atau gelandang, dan pemain penyerang. Semua itu harus menjadi satu kesatuan dalam suatu tim. Sepakbola dimainkan di lapangan rumput dan tanah yang luas dengan panjang 90 - 120 meter dan lebar 45 - 90 meter. Permainan sepakbola dilakukan dua babak dengan waktu normal 2 x 45 menit dengan waktu istirahat 15 menit. Tim yang dinyatakan menang adalah tim atau kesebelasan yang akhir permainan atau pertandingan lebih banyak memasukan bola ke dalam gawang lawan.

Di dalam permainan sepakbola ada penempatan posisi berdasarkan kemampuan yang di miliki oleh seorang pemain. Seperti posisi penjaga gawang atau goalkeeper, pemain belakang atau back, pemain tengah atau midfielder, dan pemain depan atau striker. Setiap posisi ini mempunyai tugas dan peranannya masing-masing. 
1. Penjaga Gawang atau Goalkeeper, kiper memiliki satu peran yang spesifik untuk tugasnya sendiri. Ia harus mengkontrol wilayahnya dan menghalau tembakan serta umpan silang dengan baik. Ia juga harus bisa menyarankan pemain-pemain belakang dalam penempatan posisi mereka yang secara keseluruhan "pengatur posisi" dalam situasi yang defensif.

2. Pemain belakang atau back, seperti pemain tengah, pemain belakang merupakan bagian dari sebuah unit yang mungkin terdiri dari dua pemain yang melebar (biasanya pemain bek sayap) dan dua pemain pusat bertahan. (Nama ini jelas merujuk kepada kawasan lapangan mereka yang diperlukan untuk tugasnya). Tugas utama mereka adalah untuk menggagalkan serangan apapun di bagian-bagian dari lapangan, baik di tanah dan di udara.

3. Pemain tengah atau midfielder, pemain ini adalah titik kontak antara pertahanan dan menyerang. Mereka ada sebagai bagian dari sebuah unit, sering memiliki peran yang bebas di mana mereka mencoba untuk mencakup setiap aspek dari lapangan tengah. Pemain lapangan tengah yang diperlukan secara harfiah adalah untuk pergi ke mana pun bola berada, dan terutama mereka menjadi yang terlibat dengan yang menutup ruang dan membuat ruang. Mereka berusaha untuk menguasai bola selama mungkin, dan mereka mencoba untuk mendikte permainan. Dengan demikian, pemain tengah yang sering menjadi kunci - pengambilan keputusan di tim, mencoba untuk membuat pilihan benar lewat passing dan mengontrol jalannya pertandingan.

4. Pemain depan atau striker, seperti namanya, pemain depan selalu menjadi tim penyerang utama pada tujuan dan target untuk setiap umpan-umpan ke posisi pertahanan. Pemain depan harus menjadi pemain secara keseluruhan pada bagian penempatan posisi kaki dan harus memiliki berbagai serangan, perlindungan dan kemampuan menggiring. Cukup sering striker itu melakukan perannya yang berjuang sendiri dengan kembali ke pemain pusat bertahan, mencoba untuk mengubah dan menekan lawan, atau memegang bola dan menunggu untuk dukungan.

\section{Hakikat Usia 13 - 14 tahun}

Usia 13 - 14 tahun adalah masa adolesensi, yaitu masa transisi atau peralihan dari masa anak-anak untuk menjadi dewasa. Masa ini merupakan masa pertumbuhan yang pesat, yang ditandai dengan perkembangan biologis yang kompleks. Gejala-gejala pertumbuhan dan perkembangan yang menonjol adalah dalam hal:

1. Ukuran tubuh

2. Jaringan tubuh

3. Kematangan seksual

4. Fisiologis

Anak usia 13 - 14 tahun adalah masa pubertas yang berasal dari kata latin, yaitu pubertas yang artinya adalah usia kedewasaan.

Pertumbuhan ukuran fisik mengalami percepatan pada tahun-tahun awal dan kemudian melambat, yang akhirnya pertumbuhan memanjang akan berhenti setelah mencapai usia dewasa. Setiap individu menjadi semakin jelas tumbuh ke arah tipe tubuh tertentu. Ada tiga tipe tubuh yaitu: endomorph, mesomorph, dan ectomorph. Pertumbuhan ke arah tipe ini seringkali tidak ekstrim pada tipe tubuh tertentu, melainkan bisa merupakan perpaduan antara dua tipe atau bahkan merupakan pertengahan antara ketiga tipe ini. Kecenderungan ke arah tipe tertentu akan berpengaruh terhadap perkembangan kemampuan fisik dan kemampuan geraknya. 


\section{Metode}

Metode penelitian yang digunakan dalam penelitian ini adalah metode penelitian deskriptif. Penelitian deskriptif adalah suatu metode dalam meneliti status sekelompok manusia, suatu objek, suatu set kondisi, suatu sistem pemikiran, ataupun suatu kelas peristiwa pada masa sekarang. Dengan menggunakan teknik analisis dokumenter, yaitu penelitian yang dilakukan terhadap informasi yang didokumentasikan dalam rekaman, baik suara, tulisan, atau lain-lain bentuk rekaman. Penelitian ini adalah hasil tes fisik daya ledak, kecepatan, daya tahan sepakbola peserta Milan Junior Camp 2011.

\section{Pembahasan}

Deskripsi data pada penelitian ini meliputi norma tes fisik Sepak Bola (Daya Ledak, Kecepatan dan Daya Tahan) untuk kategori Baik Sekali (A), kategori Baik (B), kategori Cukup (C), kategori Kurang (D), dan kategori Kurang Sekali (D). Jumlah total tes (Daya Ledak, Kecepatan dan Daya Tahan), rata-rata, varians, standar deviasi, berikut peneliti menyusun data lengkapnya dalam tabel di bawah ini:

Tabel. Deskripsi Data Penelitian Keseluruhan

\begin{tabular}{|l|c|c|c|}
\hline \multicolumn{1}{|c|}{ Variabel } & Daya Ledak (cm) & Kecepatan (detik) & $\begin{array}{c}\text { Daya Tahan } \\
\text { (ml/kg/min) }\end{array}$ \\
\hline Kategori Baik Sekali (A) & $>67$ & $<5,53{ }^{\prime \prime}$ & $>44,9$ \\
\hline Kategori Baik (B) & $54-67$ & $5,53-6,09 ”$ & $39,7-44,9$ \\
\hline Kategori Cukup (C) & $41-53$ & $6,10-6,65{ }^{\prime \prime}$ & $34,4-39,6$ \\
\hline Kategori Kurang (D) & $27-40$ & $6,66-7,21 ”$ & $29,1-34,3$ \\
\hline Kategori Kurang Sekali (E) & $<27$ & $>7,21{ }^{\prime \prime}$ & $>29,1$ \\
\hline Jumlah & 25548,400 & 3446,380 & 20031,800 \\
\hline Rata-rata (Mean) & 47,224 & 6,370 & 37,027 \\
\hline Standar Deviasi & 13,282 & 0,560 & 5,278 \\
\hline Varians & 176,415 & 0,313 & 27,856 \\
\hline
\end{tabular}

\section{Kesimpulan}

Berdasarkan hasil penelitian dan analisa perhitungan data maka penelitian ini dapat disimpulkan bahwa :

1. Untuk data penjaga gawang:

1. Telah didapat norma tes fisik Daya Ledak yaitu untuk kategori Baik Sekali lebih besar dari 74, kategori Baik antara 58 - 74, kategori Cukup antara 42 - 57, kategori Kurang antara $27-41$, dan kategori Kurang Sekali lebih kecil dari 27.

2. Telah didapat norma tes fisik Kecepatan yaitu untuk kategori Baik Sekali lebih kecil dari 5,47, kategori Baik antara 5,47 - 6,06, kategori Cukup antara 6,07 - 6,65, kategori Kurang antara 6,66 - 7,24, dan kategori Kurang Sekali lebih besar dari 7,24 .

3. Telah didapat norma tes fisik Daya Tahan yaitu untuk kategori Baik Sekali lebih besar dari 42,3, kategori Baik antara 36,8 - 42,3, kategori Cukup antara 31,4 36,7, kategori Kurang antara 26,0 - 31,3, dan kategori Kurang Sekali lebih kecil dari 26,0 .

2. Untuk data pemain belakang:

1. Telah didapat norma tes fisik Daya Ledak yaitu untuk kategori Baik Sekali lebih besar dari 71, kategori Baik antara 57 - 71, kategori Cukup antara 42 - 56, kategori Kurang antara $28-41$, dan kategori Kurang Sekali lebih kecil dari 28. 
2. Telah didapat norma tes fisik Kecepatan yaitu untuk kategori Baik Sekali lebih kecil dari 5,67, kategori Baik antara 5,67 - 6,12, kategori Cukup antara 6,13 - 6,57, kategori Kurang antara 6,58 - 7,03, dan kategori Kurang Sekali lebih besar dari 7,03 .

3. Telah didapat norma tes fisik Daya Tahan yaitu untuk kategori Baik Sekali lebih besar dari 44,7, kategori Baik antara 39,6 - 44,7, kategori Cukup antara 34,6 39,5, kategori Kurang antara 29,5 - 34,5, dan kategori Kurang Sekali lebih kecil dari 29,5 .

3. Untuk data pemain tengah:

1. Telah didapat norma tes fisik Daya Ledak yaitu untuk kategori Baik Sekali lebih besar dari 67, kategori Baik antara 54 - 67, kategori Cukup antara 40 - 53, kategori Kurang antara 27 -39, dan kategori Kurang Sekali lebih kecil dari 27.

2. Telah didapat norma tes fisik Kecepatan yaitu untuk kategori Baik Sekali lebih kecil dari 5,64, kategori Baik antara 5,64 - 6,12, kategori Cukup antara 6,13 - 6,60, kategori Kurang antara 6,61 - 7,08, dan kategori Kurang Sekali lebih besar dari 7,08 .

3. Telah didapat norma tes fisik Daya Tahan yaitu untuk kategori Baik Sekali lebih besar dari 45,8, kategori Baik antara 40,3 - 45,8, kategori Cukup antara 34,9 40,2, kategori Kurang antara 29,5 - 34,8, dan kategori Kurang Sekali lebih kecil dari 29,5 .

4. Untuk data pemain depan:

1. Telah didapat norma tes fisik Daya Ledak yaitu untuk kategori Baik Sekali lebih besar dari 61, kategori Baik antara 50 - 61, kategori Cukup antara 40 - 49, kategori Kurang antara 29 - 39, dan kategori Kurang Sekali lebih kecil dari 29.

2. Telah didapat norma tes fisik Kecepatan yaitu untuk kategori Baik Sekali lebih kecil dari 5,31, kategori Baik antara 5,31 - 6,04, kategori Cukup antara 6,05 - 6,78, kategori Kurang antara 6,79 - 7,51, dan kategori Kurang Sekali lebih besar dari 7,51 .

3. Telah didapat norma tes fisik Daya Tahan yaitu untuk kategori Baik Sekali lebih besar dari 44,2, kategori Baik antara 39,2 - 44,2, kategori Cukup antara 34,2 39,1 , kategori Kurang antara 29,2 - 34,1, dan kategori Kurang Sekali lebih kecil dari 29,2 .

\section{Referensi}

Andi Suntoda, Tes Pengukuran dan Evaluasi Dalam Cabang Olahraga. Bandung: UPI, 2009

Bauer, Gerhard, Soccer Technique, Tactics, dan Team Work. NewYork: Company. Inc, 1993.

Bompa, Tudor. O. Periodization Theory and Methodology of Training $4^{\text {th }}$ Edition, Canada, Toronto

Daral Fauzi R, Tes Keterampilan Sepak Bola Usia 10 - 12 Tahun, Jakarta: Sekretariat jenderal departemen pendidikan Nasional, 2009.

FIFA, Physical preparation and physical development and training, Chapter 8

Gambetta, Vern, Soccer Speed. USA: Gambetta Sport Training System, 1998.

Harsono, Latihan Kondisi Fisik. Jakarta: Pusat Pendidikan dan Penataran, 1993.

Moh. Moeslim, Tes dan Pengukuran Kepelatihan. Jakarta: KONI, 1993.

Nurhasan, Tes dan Pengukuran Pendidikan Olahraga. Bandung: FPOK IKIP, 1988. 
Ridwan Widyagama, Norma Tes Keterampilan Sepakbola (juggling, shooting, long pass) Untuk Kategori Usia 13 - 14 Tahun. Jakarta: UNJ, 2012. 